\title{
'n Retoriese analise van die vyf lykdigte in T.T. Cloete se Allotroop
}

Louise Viljoen

Departement Afrikaans en Nederlands

Universiteit van Stellenbosch

STELLENBOSCH

\begin{abstract}
A rhetorical analysis of the five funerary poems in T.T. Cloete's Allotroop

This article works from the premise that these poems form part of a tradition that can be traced back to the funerary poetry of the Dutch Renaissance and from there to the funeral orations of Classical times. After referring to the current revival of interest in rhetoric, attention is given to the role which rhetoric played in Renaissance poetics and the influence it had on the practice of writing funerary poetry. The funerary poems in Cloete's Allotroop are then analysed, making use of the Renaissance descriptions of and prescriptions for funerary poetry researched by S.F. Witstein in Funeraire poëzie in de Nederlandse Renaissance. These analyses prove that Cloete's poems make use of the elements hasic to the Renaissance funerary poem and the classical funeral oration namely praise (laus), mourning (uctus) and consolation (consolatio) and that the rhetorical terminology devised centuries ago can still be useful in the reading of these poems.
\end{abstract}

\section{Inleiding}

In verband met T.T. Cloete se derde bundel Allotroop (1985) het verskeie lesers al daarop gewys dat die bundel sterk konsentreer op ervarings van pyn, siekte, aftakeling en dood waardeur die mens uiteindelik insig verwerf in die Goddelike bestel (Gräbe, 1985; Brink, 1985; Hugo, 1985; Gilfillan, 1985; Hambidge, 1985; Grové, 1985; Kannemeyer, 1990:454). Dit is dus nie vreemd dat daar in hierdie bundel ook gedigte oor en aan gestorwenes aangetref word nie. Hierdie gedigte word deur titel of inhoud geïdentifiseer as gedigte geskryf by geleentheid van 'n sterfgeval: "1 in memoriam m." (75), "2 in memoriam lenie" (101), "in memoriam brezjnjef" (77), "in memoriam herman" (79) en "Allofrasie" (81). Met hierdie lykdigte (die benaming wat in die gedig 
"Allofrasie" daaraan gegee word) plaas Cloete homself in 'n ryk tradisie van verse oor gestorwenes in die Afrikaanse literatuur wat strek vanaf Totius se verse oor die dood van sy kinders in Passieblomme tot by Johann de Lange se verse oor die dood van 'n pop-ikoon soos James Dean in Snel grys fantoom (vgl. ook die studie van Van Zyl, 1987:109-118). Cloete lewer egter 'n unieke bydrae deur naas die Afrikaanse tradisie met die struktuur en inhoud van hierdie vyftal gedigte ook in te speel op die lykdigte van die sewentiende-eeuse Nederlandse digters soos Hooft, Huygens en Vondel. Die lykdigte van hierdie digters was op hulle beurt geïnspireer deur 'n tradisie wat teruggevoer kan word tot by die grafredes van die Klassieke Oudheid. Soos wat Witstein in haar studie Funeraire poëzie in de Nederlandse Renaissance (1969) aantoon, het die praktiese instruksies wat Renaissancistiese poëtikas aan digters in die algemeen en digters van lykdigte spesifiek gegee het 'n sterk retoriese onderbou gehad.

Hierdie vyftal lykdigte van Cloete kan dus gelees word teen die agtergrond van die retoriese tradisie wat reeds meer as vyf-en-twintig eeue oud is en tans weer 'n kragtige opbloei beleef. Geskiedenisse van die retorika plaas gewoonlik die beginpunt daarvan in die Atheense demokrasie van die vyfde en vierde eeu voor Christus en in die republikeinse Rome van die tweede eeu voor Christus. Tydens die verval van die Romeinse kultuur in die tweede en derde eeu na Christus gaan die bestudering van die Klassieke retorika agteruit voordat dit weer ' $n$ laaste oplewing beleef in die Christelike milieu en wel in die werk van Augustinus (Leeman \& Braet, 1987:2-4). In die Middeleeue maak die retorika 'n vaste deel uit van die skoolopleiding as deel van die sogenaamde trivium bestaande uit die grammatika, dialektika en retorika. Tydens die Renaissance herwin die retorika weer sy vitaliteit en lewenskrag voordat die koms van die Verligting en die Romantiek 'n afname in die invloed daarvan inlui. Tans is daar egter weer 'n dramatiese oplewing van belangstelling in die retoriese tradisie en word retoriese ondersoeke gedoen op terreine wat wissel van die sielkunde tot by die ekonomie (vgl. Roberts \& Good, 1993:3). Hierdie oplewing van die retoriese tradisie word in sekere oorde gesien as 'n sterk werktuig nie net in die dekonstruksie van die objektivistiese pretensies van geesteswetenskaplike ondersoek sedert die negentiende eeu nie, maar ook in die rekonstruksie wat moet volg op sodanige ontmaskerings (vgl. Simons, 1990:vii). Sekere ondersoekers meen selfs dat die terugkeer na die retoriese tradisie 'n kenmerk is van die postmodemisme, terwyl ander meen dat dit eerder gesien moet word as 'n analitiese modus waardeur die fragmenterende aspekte van die postmodernistiese kondisie teengewerk kan word en die rehabilitasie van 'n metateorie of grand theory verwesenlik kan word (vgl. Roberts \& Good, 1993:10). My lesing van Cloete se gedigte gee nie voor om deel te word van hierdie uitgebreide diskussie oor die rol van die retorika met 
betrekking tot die ander literêr- en kultureel-kritiese diskoerse van ons tyd nie, maar wil tog aantoon hoe hierdie lykdigte 'n eeue-oue retoriese tradisie bevestig én verbreed deur daarop te improviseer.

\section{Struktuurelemente van die lykdig}

Alhoewel die retorika aanvanklik gerig was op die spesifieke (die daaglikse oplossing van konkrete vraagstukke) en die digkuns op die universele ('n korrigerende en idealiserende weergawe van die werklikheid), is die digkuns vanaf die Romeinse keiserstyd tot by die Renaissance toenemend verbind met die retorika. Die verband tussen die retorika en die digkuns is des te sterker in die geval van die lykdig wat as geleentheidsvers oor elemente van die spesifieke ('n bepaalde persoon se dood) sowel as die pragmatiese (soos byvoorbeeld die leniging van smart) beskik. Witstein se vergelyking van 'n aantal poëtikas uit die Renaissance met voorskrifte vir die Klassieke grafrede en die lykdigte van Vergilius, Ovidius en Statius toon aan dat hulle presies dieselfde basiese struktuurelemente ken, naamlik dié van lofspreking (laus), roubeklag (luctus) en vertroosting (consolatio) (1969:119). Sy gaan verder na hoedat Scaliger (Lyon 1561), Corraea (Venesië 1569) en Pontanus (Ingolstadt 1594) in hulle poëtikas omskryf hoedat hierdie drie basiese struktuurelemente beslag kan kry in 'n lykdig. 'n Vlugtige omskrywing hiervan is noodsaaklik as aanloop tot my eie lesing van Cloete se gedigte.

Met die inset word daar in hierdie poëtikas klem gelê op decorum, 'n verwysing na die wenslikheid daarvan om rekening te hou met die staat van die oorledene ter ere van wie die gedig geskryf word. Dit sluit aan by retoriese voorskrifte van sover terug as Quintilianus wat nie net daarop wys dat daar harmonie moet wees tussen die persoon of saak en die uitdrukking daarvan in taal nie, maar dat ook kennis geneem moet word van die aard van die gehoor (Witstein, 1969:101-103). Verder word daar ook in hierdie poëtikas advies gegee in verband met die soort inleiding (prooemium) wat in die lykdig gebruik kan word: die rou kan reeds hier tot uiting kom deur kalm en gematig te begin ooreenkomstig die gevoelens van die bedroefdes en verslaenes, deur uit te vaar teen die dood of die doodsoorsaak (vituperatio) of deur te verwys na die dilemma van die spreker wat nie weet of hy moet spreek of swyg ten aansien van die smart nie (Witstein, 1969:103-105).

$\mathrm{Na}$ die inleiding volg die lofprysing (laus) wat uit kompositoriese oogpunt gesien die plek inneem van die vertelling of feiterelaas (narratio) in die gewone redevoering en wat dan ook dikwels narratiewe elemente bevat. Hierdie vertelling word sodanig ingeklee dat die grootste moontlike bewondering en simpatie vir die deugde van die gestorwene sal ontstaan. Verskillende plekke 
(loci) waar stof gevind kan word vir die lofprysing van persone word byvoorbeeld deur Corraea aangedui: beroep, leeftyd, geestesgawes, voortbrengsels, intellek (Witstein, 1969:106-107). Lofprysing is veral dominant in die geval van lykdigte oor die afsterf van belangrike persone: deugde soos wysheid, regverdigheid, standvastigheid en omsigtigheid kan in hierdie soort geval besing word. In die geval van susters en dogters kan verwys word na hulle kuisheid en ingetoë sedes, by 'n eggenote haar deug as huweliksgenoot en in die geval van kinders of jongelinge die liefde wat die omgewing die persoon betoon het (Witstein, 1969:116-117).

Die poëtikas adviseer ook dat die lofprysing van die gestorwene opgevolg word met 'n aanwysing van die betekenis van die verlies (iacturae demonstratio). Terwyl die verteltrant steeds meer bewoë word, kan die relaas met uitbreidinge aangevul word sodat die gemis aan die dooie steeds sterker gevoel word en slegs die roubeklag (luctus) nog hierop kan volg. Die iacturae demonstratio neem 'n tussenposisie in die lykdig in omdat dit tegelyk 'n naspel van die lofprysing en voorspel tot die roubeklag is. Die verhouding tussen die stof en die status van die gestorwene in ooreenstemming met die beginsel van decorum is ook ter sprake by die roubeklag: namate die verlies persoonliker is, word die roubeklag gevoelvoller en vind sugte, trane en klagte 'n plek in die lykdig. Die oproep (adhortatio) tot rou hoef ook nie net beperk te word tot mense nie, maar kan ook uitgebrei word tot diere en lewelose dinge soos in dié voorbeelde uit die digkuns waar die rou selfs die orde van die natuur versteur. In die geval van die roubeklag word daar ook dikwels na die doodsoorsaak (causa) verwys. Hierop volg dan die vertroosting (consolatio) wat dikwels die aandag van die bedroefdes van hulle eie smart afgewend het deur die persoonlike leed te verhef tot 'n algemene vlak.

Die hieropvolgende analises sal probeer toon dat die basiese struktuurelemente wat Witstein geïdentifiseer het in die poëtiese teorie en praktyk van die Nederlandse Renaissance ook aanwesig is in die lykdigte van Cloete en dat die retoriese terminologie wat sy hanteer, steeds nuttig kan wees by 'n gesprek oor hierdie gedigte.

\section{3. " 1 in memoriam m." en " 2 in memoriam lenie"}

Alhoewel hierdie twee lykdigte in verskillende afdelings van die bundel Allotroop staan (en dus buite die relatief hegte groep wat die ander vorm deur hulle naasliggendheid in afdeling drie), word hulle duidelik aan mekaar verbind deur die numering in die titels. Dit laat die vermoede ontstaan dat die gestorwe "magdalena" oor wie die eerste gedig handel dieselfde persoon is as die "lenie" na wie in die tweede gedig verwys word (Lenie word immers 
algemeen gebruik as 'n noemnaam vir iemand met die doopnaam Magdalena). Dit lyk dus asof hierdie twee "in memoriam"-gedigte (geskei deur hulle plasing in die bundel, maar verenig deur hulle fokus op dieselfde gestorwene) 'n verdere manifestasie is van die "eenderse andershede" (Brink, 1985:17) van die bundel se verwysings na allotropie, die chemiese verskynsel dat een en dieselfde stof kan voorkom in diverse vorme of modifikasies. Hierdie twee gedigte wat skynbaar as 'n soort tweeluik oor dieselfde gestorwene handel, kan dus in aansluiting by mekaar gelees word.

Die struktuurelement wat in die eerste van hierdie twee lykdigte naamlik " 1 in memoriam m." domineer, is die roubeklag (luctus):

so 'n dag was bestem magdalena
vir ons om jou graf toe te dra
en te bêre koud en bleek en nat
afskuwelik soos die verloopte kat
moes ons oor die plasse skugter

trap kat en reën het ons ontnugter

beteuterd en klam misrabel

van die fabel

Die gebruik van die ietwat formele doopnaam Magdalena (in teenstelling met die gebruik van die noemnaam Lenie in die tweede gedig) sluit aan by die toon van die spreker in die gedig: kort(af), ietwat afstandelik, waarskynlik stom van verdriet en misrabelheid oor die ellende van die begrafnisdag. Hierdie spreker is kennelik ' $n$ familielid of nabye vriend soos afgelei kan word uit die feit dat hy een van die draers op die begrafnis is ("vir ons om jou graf toe te dra"). Alhoewel die gestorwene aangespreek word, is die fokus van hierdie gedig gerig op die agterblywendes se smart. Soos wat dit ook by geleentheid in die Klassieke en Renaissancistiese lykdig gebeur (vgl. Witstein, 1969:114), is daar die suggestie dat die natuur saam rou en dat die dag se triestigheid 'n teken is van rou oor die gestorwene: "so 'n dag was bestem magdalena / vir ons om jou graf toe te dra / en te bêre koud en bleek en nat / afskuwelik" (vgl. ook die eggo van Leipoldt se "Aan 'n seepkissie" wat in die beginreël klink: "En jy was bestem, soos jy weet, seepkissie, / Daar oorkant in Eng'land tot doodkis vir hom!").

Die element van rou is implisiet teenwoordig in die reaksie van die agterblywendes. Hulle misrabelheid op dié triestige dag word voorgestel in terme van die volgende vergelyking: "soos die verloopte kat / moes ons oor die plasse skugter / trap". Alhoewel daar hier sprake mag wees van 'n verwysing na 'n spesifieke kat ("die verloopte kat"), dink die leser onwillekeurig in terme 
van al die verloopte én weggeloopte katte wat in sprokies en fabels voorkom. Die beeld van 'n eienaar wat ontslae wil raak van 'n kat en die dier selfs probeer verdrink, kom meermale voor vanaf verhale soos "Die musikante van Bremen" en "Die gestewelde kat" tot by die liedjie oor ou Jan Wilson se kat wat altyd weer tengkeer. In die daaropvolgende reëls word die agterblywendes nie meer self met die verloopte kat in die reën vergelyk nie, maar word hulle deur die kat en reën ontnugter ("kat en reën het ons ontnugter / beteuterd en klam misrabel / van die fabel") sodat dit moontlik word om die "verlooptheid" van die kat te lees as 'n ironiese verwysing na fisiese degenerasie van die gestorwene waarop in die tweede gedig gesinspeel word. Die vloeiende, omate en selfs breedsprakige styl van Renaissancistiese lykdigters soos Vondel en Hooft word in hierdie lykdig vervang met 'n gestrooptheid wat ook manifesteer in die eenvoudige prosodie (vgl. die paarryme), die gebrek aan interpunksie en die elliptiese sinsbou.

Waar die eerste twee van die gedigte in hierdie tweeluik rou oor die gestorwene vanuit die perspektief van 'n agterblywende, is die tweede gedig 'n vertroosting (consolatio) van die gestorwene deur die spreker in die gedig. In die lig daarvan dat die spreker in hierdie gedig nie 'n mens is nie maar God, is dit veelseggend dat die gestorwene in die titel genoem word op die intieme noemnaam "lenie". By wyse van kontras met die eerste gedig waarin die gestorwene deur 'n menslike spreker heel formeel "magdalena" genoem is, word daar dus gesuggereer dat die mens se werklik intieme verhouding met God is en nie met ander mense wat magteloos vanaf ' $n$ afstand toekyk by die dood nie. Dat hierdie intimiteit tussen God en mens nie sonder sy ysingwekkende paradokse is nie, sal wel uit die gedig blyk:

ek is met jou wees onbevrees

ek gaan jou binnekort ontbind

uit jouself straks behoort jy net aan my

ek het jou op uit- en afsondering voorberei

jy ken dit woordelik vandat jy 'n kind

was het jy jesaja mos tot troos gelees

ek het jou na my Naam geformuleer

en jou met kosbare geloof toegenus

minder werd vir die daaglikse meer vir die dood

my stem word helderder in uiterste nood

gekarnuffel was jy van my bewus

gekneus moet jy tot my terugkeer 
die dowes wat ore het

moet hoor dié wat oë het maar blind

is maak ek van heinde en ver bymekaar

om jou gehawend te laat vaar

broer en suster man en kind

dat hulle op my hardhandige doen met jou let

deur water tot by jou mond

moet jy as ek roep gaan

jy't immers nooit kon dink

dis praatjies nie alleen dié verdrink

(sê revius) wat gaan staan

in die stroom en soek na grond

dan is daar ook nog die vuur

wat jy moet glo nie sal skroei nie

dié wat ek met liefde bederf

moet deur water en deur vuur sterf

die water sal nie oor jou vloei nie

en die vuur kán jy verduur

Soos wat die onderskrif by die titel aandui, is dié lykdig gebaseer op passasies uit Jesaja 43 en kan die spreker in die gedig geïdentifiseer word as die God van hierdie Ou-Testamentiese Bybelboek. Die gedig begin byvoorbeeld met 'n herskrywing in kleinletters ("ek is met jou wees onbevrees") van die bekende woorde uit Jesaja 43:5: "Wees nie bevrees nie, want Ek is met jou" (dit blyk uit woordkeuses soos "wees onbevrees" eerder as "Moenie bang wees nie" dat die Cloete-gedig teruggaan op die ou eerder as die nuwe Afrikaanse vertaling van die Bybel). Die paradoksale van die vertroosting wat hierdie God die gestorwene bied, blyk uit die belofte wat in reëls 2 en 3 aan die gestorwene gemaak word: "ek gaan jou binnekort ontbind / uit jouself". Die kundige gebruik van die enjambement maak seker dat die leser die fisieke implikasies van hierdie Goddelike versekering aan die gestorwene (die fisiese ontbinding na die dood) besef, voordat daar verder gelees word na die geestelike implikasies (die ontbinding uit die menslike staat om verenig te word met God na die dood). Op hierdie manier word die vertroosting dus sterk gelaai met ironie. In die volgende uitspraak in die gedig is vertroosting weer paradoksaal verbind met 'n soort besitlikheid: "straks behoort jy net aan my" is naamlik 'n herskrywing van die bekende gedeelte uit Jesaja 43 vers 1 wat lui: "Ek het jou by jou naam geroep; jy is myne!". Die volgende reël ("ek het jou op uit- en afsondering voorberei") bou voort hierop deurdat dit op verskillende maniere gelees kan word: as vertroostende versekering dat die gestorwene een van God 
se uitverkorenes en dus sy beskermling is, maar ook dat hierdie uitsondering gelei het tot haar afsondering van ander. In die volgende reëls ("jy ken dit woordeliks vandat jy 'n kind was / het jy jesaja mos tot troos gelees") klink dit byna asof die goddelike spreker dit nodig ag om hierdie paradoksale vertroosting retories te bekragtig met 'n verwysing na die outoriteit van die Bybelboek waarin hierdie beloftes van hom immers opgeteken is.

In die tweede strofe word die gestorwene vertroos met die versekering dat sy na die Naam van God en tot sy eer geformeer is (in 'n herskrywing van Jesaja 43 vers 7). Sy word ook getroos dat sy deur God "met kosbare geloof toegerus" is om die lyding te verduur wat Hy ironies genoeg stuur. Die troos geleë in die ervaring van die "uiterste nood" (r. 4), die "gekarnuffel" (r. 5) en die "gekneus" (r. 6) is dat die gelowige juis hierdeur uitsonderlik ingestem raak op God en bewus raak van sy teenwoordigheid. Volgens die derde strofe moet die gestorwene vertroosting vind in die nut wat haar lyding vir ander gehad het: die troos lê daarin dat ander God se teenwoordigheid en mag kan ervaar deur te let op sy "hardhandige doen" (r. 6) met haar. Onder "die dowes wat ore het" en "dié wat oë het maar blind / is" (vgl. Jesaja 43 vers 8 ) wat bymekaar gemaak word om die gestorwene "gehawend te laat vaar", tel "broer en suster" en "man en kind" waaruit die leser kan aflei dat die gestorwene 'n volwasse vrou was. Die implikasie is dat hulle bymekaar gemaak word sodat hulle ' $n$ les kan leer uit die wyse waarop God met hierdie gestorwene handel. Die woordspel in die frase "gehawend laat vaar" modifiseer hierdie implikasies nog verder: dat God die gestorwene in 'n fisies gehawende toestand laat sterf het (met "laat vaar" gelees as "laat gaan") en dat God tog op hierdie uitvaart die gestorwene "gehawend" (beskermd asof in 'n hawe) "laat vaar" (die doodstog soos met 'n skip oor water laat aanpak waarby die woord "uitvaart" se assosiasies met die sewentiende-eeuse lykdigte ook 'n rol speel).

Sowel strofe vier as strofe vyf waarin daar verwys word na die gestorwene se verhouding met water en vuur is gebaseer op Jesaja 43 vers 2: "As jy deur die water gaan, is Ek by jou; en deur die riviere - hulle sal jou nie oorstroom nie; as jy deur vuur gaan, sal jy jou nie skroei nie, en die vlam sal jou nie brand nie". Wat in Jesaja na 'n versekering klink, word in die begin van die vierde strofe as 'n verpligting en 'n toets aan die gelowige voorgehou: "deur water tot by jou mond / moet jy as ek roep gaan". Hierdie paradoksale trooswoord klink na die uitspraak van 'n God wat onvoorwaardelike gehoorsaamheid eis van diegene aan wie hy sy beskerming bied. Die gestorwene word amper verbaas en verontwaardig deur hierdie onverbiddelike God daarop gewys dat sy tog nie kon dink dat dit wat sy in Jesaja gelees het onwaar was nie (vgl. "jy't immers nooit kon dink / dis praatjies nie"). In 'n heel besondere variant van die retoriese 
tegniek om outoriteite by te roep om argumente te bekragtig, word die sewentiende-eeuse Nederlandse Christelike digter Revius bygehaal: "alleen dié verdrink / (sê revius) wat gaan staan / in die stroom en soek na grond". Die rare is dat God hier een van sy 'dienaar-digters' in 'n soort omgekeerde hiërargie aanroep om sy paradoksale trooswoorde aan hierdie gestorwene bykomende gewig te gee. Die troostende is volgens die vyfde strofe dat beproewing en lyding as 't ware die waarmerk van God se liefde is: "dié wat ek met liefde bederf / moet deur water en deur vuur sterf" (let op die dubbelsinnige gebruik van die woord "bederf" wat tegelykertyd sinspeel op ontbinding en verwenning).

Van die lykdig se drie tradisionele struktuurelemente lof, rou en troos, is troos ongetwyfeld die sterkste teenwoordig in hierdie gedig. Daar word slegs op indirekte wyse lof gebring aan die gestorwene wat skynbaar moedig en volhardend gelowig ("vandat jy 'n kind / was het jy jesaja mos tot troos gelees") die "uiterste nood", die "gekarnuffel" en die "gekneus" verduur het. Van rou is daar weinig sprake omdat die spreker in hierdie gedig juis dié God is wat uiteindelik nou in die dood die mens 'terugkry' wat eintlik syne is (vgl. Jesaja 43 vers 1: "Ek het jy by jou naam geroep, jy is myne"). Cloete sluit dus op strukturele vlak aan by die Klassieke en Renaissancistiese lykdigte, maar innoveer daarop deur as 't ware die 'subteks' of 'dubbele bodem' van die Goddelike spreker se vertroostinge in verband met lyding en die dood (hier byna woordeliks oorgeneem uit die Bybel) sigbaar te maak deur die ironiese en paradoksale aard daarvan uit te lig. Die strawwe vertroosting wat die spreker in hierdie gedig die gestorwene bied, herinner die leser byna onwillekeurig aan die "ruwe rasende woordeskat van Jehova" waarvan melding gemaak word in die gedig "woordeskat van jeremia en sefanja" op p. 103 in Allotroop. Hierdie lykdig is dus nie net 'n geleentheidsvers waardeur daar troos gesoek word in die geval van 'n naasbestaande se dood deur middel van die aanwending van 'n bomenslike figuur as spreker in die gedig nie, maar ook 'n subtiele interrogasie van die Bybelse voorstelling van lewe, lyding en dood.

\section{4. "in memoriam brezjnjef"}

Met die gedig "in memoriam brezjnjef" beweeg Cloete besonder na aan die voorbeelde van lykdigte uit die Nederlandse Renaissance. Hierdie gedig geskryf by die dood van die Russiese staatshoof Leonid Brezjnjef (1906-1982) herinner naamlik aan die lykdigte wat Vondel, Hooft en ander geskryf het by die geleentheid van openbare figure se dood. Cloete se gedig is hoofsaaklik gebou rondom die lofprysing en vertroosting terwyl 'n element van die roubeklag ook voorkom: 
die tagtig waarvan 'n uitverkore jood gepraat het is jy sónder sý God se genade toegelaat so sou mens sê om te has jy lê met sorg gegrimeer in staatsie netjies gekamde hare met dekorasie van linte en medaljes lê jy gereinig tot die nael

jy moes deur 'n ánder se besluit vroeg of laat die sogenaamde ewige gelukstaat vir ewig laat vaar vir miljoene het jy bepaal sus of so die beste polit- of mediese raad kon die beersterk dikvellige gelaat en die bonkige swar liggaam en brein nie staal teen degenerasie nie die ruie wysbroue die ruwe gesigvlees die eie bly behoue vir nog 'n baie klein tydjie voor die bederf daar is darem tóg iets meer as vlees en been heilsplanne tendeer om stadiger te verdwyn in die agtergrond en eindelik te sterf die denke van navolgers én vyande kontinueer jou nog hulle bly jou 'n wyle reproduseer in foto's of beelde op 'n plein en laat jou in boeke in die perfektum swerf by die steppewolwe is een van die trop ook leier maar hulle almal eindig gelykop onder die sneeu in die klei van die kommune dood bowendien (vra marsman) is dit om't ewe of ons sonder hiernamaals groot of klein lewe en of ons hoegenaamd onderskei tussen menslik klein en groot 


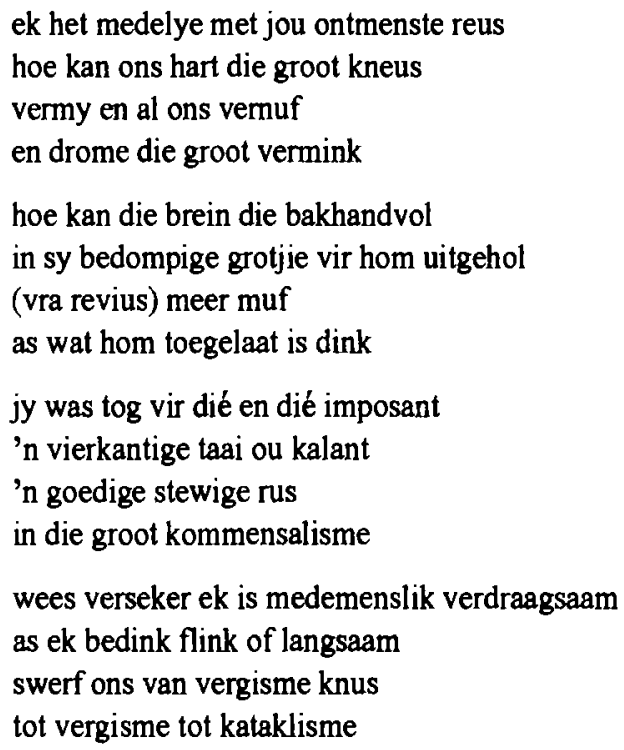

Die retoriese maneuvers in die gedig word onderlê deur 'n besonder veeleisende rymskema (aabc ddbc aaec aaec ffgh iigh iigh jjkl ens.) wat die strofes deur middel van rymklanke met mekaar verbind om die informele klank te skep van die geselstoon waarmee die gestorwene aangespreek word. Hierdie intimiteit kontrasteer sterk met die formele wyse waarop die Renaissancistiese en Klassieke lykdigte handel met die dood van 'n vername persoon en is waarskynlik daarop gemik om nie net die gestorwene se menslikheid te beklemtoon nie, maar ook sy status en dié van sy ideologie so 'n bietjie te ondermyn. Die posisie van die spreker met betrekking tot sy onderwerp is dus ' $n$ besonder interessante aspek van hierdie lykdig. Retoriese handleidings wys daarop dat die digter die goeie gesindheid van sy gehoor kan verseker deur sy eie posisie met betrekking tot die onderwerp onder bespreking te omskryf (Witstein, 1969:58-59). Die boeiende in die geval van hierdie gedig is dat dit nie lyk asof die spreker die lofprysing in hierdie lykdig uitspreek omdat hy enige besondere verband met of verpligting teenoor die gestorwene voel of hom as staatsman bewonder nie. Hy identifiseer homself eerder op menslike vlak met die gestorwene ("ek het medelye met jou ontmenste reus" sê hy in strofe 10), maar val buite die kring van diegene wat hom 'n indrukwekkende leier gevind het en sy ideologie gedeel het ("jy was tog vir dié en dié imposant" is sy ironies onttrokke kommentaar in strofe 12). Retories gesproke sou hierdie gebrek aan formaliteit en gemoedelike toon van die gedig beskryf kon word as 'n gebrek aan decorum waarvolgens die styl van die lykdig rekening moet hou 
met die staat van die oorledene. In hierdie geval het dit egter die funksie om die menslike weerloosheid van hierdie vroeër magtige wêreldleier én sy ideologie te beklemtoon.

Die dominante element in hierdie gedig vir 'n gestorwe staatsman is die lofprysing. Sekere Renaissancistiese poëtikas wys daarop dat die lofprysing op kompositoriese vlak die plek inneem van die vertelling of beskrywing (narratio) en dikwels ook narratiewe elemente bevat. Hierdie narratiewe lofprysing begin in die geval van Cloete se gedig met 'n verwysing na die ouderdom waarop hy gesterf het (een van die loci waar die stof vir die lofprysing gevind kan word volgens die retoriese voorskrifte - Witstein, 1969:107). Reeds in die begin van die gedig vind daar iets van 'n relativering van die gestorwene se posisie plaas - 'n relativering wat dui op die spreker se ironiese onttrokkenheid en voonuitwys in die rigting van die gedig se konklusie waarin daar uit hierdie spesifieke geval veralgemeen word oor die menslike geskiedenis as 'n swerf tussen "vergismes". Daar word naamlik opgemerk dat Brezjnjef toegelaat is om die hoë ouderdom wat in die Bybel genoem word (vgl. Psalm 90 vers 10) te haal sonder dat hy binne die gesag en genade van 'n God geleef het. Die narratio word in strofes twee tot vier voortgesit met 'n verwysing na die gestorwene se lyk wat "met dekorasie / van linte en medaljes" in staatsie lê (strofe 2), na sy beskikkingsmag as staatsman ("vir miljoene het jy bepaal // sus of so" in strofes 3-4) en na sy fisiese en intellektuele attribute (strofes 4 en 5). Vervleg met hierdie narratio waarin sekere loflike eienskappe van die gestorwene ter sprake kom, is daar egter ook verwysings waarin die onstuitbaarheid van die dood verdoem word (vituperatio). Die dood word voorgestel as iets wat hierdie gestorwene weggeneem het uit "die sogenaamde ewige gelukstaat" (strofe 3) en ook die "degenerasie" (strofe 4) en "bederf" (strofe 5) van die liggaam en brein teweegbring.

$\mathrm{Na}$ hierdie lofspraak en verwysings na die dood, is die grondtoon van die volgende vier strofes een van vertroosting sodat die consolatio ook aan die beurt kom in hierdie lykdig. Nie sonder 'n mate van ironie nie word die gestorwe en ongelowige Kommunis vertroos met die uitspraak "daar is darem tóg iets meer / as vlees en been" (strofe 6). As vertroosting word die gestorwene gewys op die dinge wat wel vir 'n tyd na sy dood sal bly voortbestaan soos die heilsplan waarvan hy deel was (strofe 6). Daarbenewens sal hy - al is dit dan net vir "'n wyle" - in die denke van ander, foto's, standbeelde en boeke by voortbestaan (strofe 7). Strofe 8 gaan soek die vertroosting in 'n vergelyking (die gebruik van 'n exemplum is 'n bekende retoriese strategie om 'n argument te versterk) tussen die gestorwene en 'n steppewolf (vgl. Van Wyk Louw se gebruik van die beeld van die wolfdoring 
wat wolwe bloei in verband met die ekspansie van die Kommunisme in "Hongarye: November 1956" in Tristia - 1962:121-122). Ook by die steppewolf gebeur dit dat een uitstyg om die leier van die trop te wees, maar dat hy in sy dood gelyk word met die ander in die klei "van die kommune" (laasgenoemde woord weer ironies gerig aan die gestorwe Kommunis). Die gestorwene moet hom dus daaraan troos dat sy gelykmaking met ander in die dood strook met die grondbeginsels van sy ideologie en boonop een van die onontwykbare prosesse van die natuur is. In strofe 9 word die argumente ter vertroosting van die gestorwene versterk deur die byhaal van 'n outoriteit in die persoon van die vroeg-gestorwe Nederlandse digter Marsman (1899-1940) wat sal bevestig dat dit "om 't ewe" is of jy groot of klein lewe of sterwe.

Die laaste vier strofes van die gedig vorm 'n eenheid waarin die spreker hom identifiseer met die lot van die gestorwene deurdat hy algemene afleidings maak in verband met die menslike kondisie op grond van hierdie spesifieke geval. Hier tree hy vir die eerste keer eksplisiet op die voorgrond nadat sy instelling tot op hierdie punt slegs implisiet afgelei kon word. In die inset van die tiende strofe spreek hy sy medelye (wat miskien gesien kan word as 'n vorm van rou) uit met die gestorwene wat in die dood ontneem is van sy belangrikheid net soos wat hy in die lewe deur sy posisie ontneem is van sy menslikheid ("ek het medelye met jou ontmenste reus") omdat hierdie lot alle mense insluitende die spreker raak (soos wat blyk uit sy gebruik van die woord "ons"). Weer word die dood verdoem, nou as die een wat die mens se hart "kneus" sowel as sy vernuf en drome "vermink". Strofe 11 suggereer dat die vraag wat in strofe 10 gestel is, nie werklik deur die menslike brein beantwoord kan word nie vanweë die beperkinge daarvan. Ironies genoeg word die (Christelike!) digter Revius eg retories as outoriteit bygehaal om hierdie stelling te staaf met sy beeld van die brein as 'n beperkte "bakhandvol" in "'n bedompige grotjie".

In die twaalfde strofe blyk die spreker se ietwat teësinnige bewondering en lof vir die gestorwene: as manifestasie van die groot "kommensalisme" (die saamleef van verskillende persone of groepe sonder onderlinge afhanklikheid of benadeling - WAT), gee hy toe dat hy Brezjnjef sou moes prys vir sy gehardheid, uitgeslapenheid en menslikheid, soos wat blyk uit die beskrywing van hom as "'n vierkantige taai ou kalant / 'n goedige stewige rus". In plaas daarvan dat die spreker reeds by die inleiding sy eie geskiktheid as lykdigter aandui, doen hy dit in die slotstrofe van die gedig wanneer hy sy verdraagsaamheid uitspreek teenoor iemand van wie hy skynbaar ideologies verwyderd staan: "wees verseker ek is medemenslik verdraagsaam as ek bedink" (strofe 13). Dit voer hy dan aan as waarmerk vir die eerlikheid en 
integriteit waarmee hy 'n konklusie trek uit die dood van hierdie staatsman: "flink of langsaam / swerf ons van vergisme knus / tot vergisme tot kataklisme". Cloete improviseer dus hier op die tradisie van die lofprysende lykdig uit die Klassieke tyd en die Renaissance deur op ironiese wyse te skryf oor 'n gestorwene wat hy byna teen sy sin en slegs gedeeltelik bewonder. Dit is veelseggend én raar binne Cloete se oeuvre dat die spreker na aanleiding van hierdie geval tot die gevolgtrekking kom dat die menslike lewe (sy eie inkluis as die leser die verwysing na "ons" kan glo) en die menslike geskiedenis 'n swerf van die een foutiewe -isme ("vergisme") na die ander behels en dat dit uiteindelik lei tot die totale destruksie van alle lewe geïmpliseer deur 'n "kataklisme".

\section{5. "in memoriam herman"}

Die gedig "In memoriam herman" getuig eweneens van 'n innoverende omgang met die tradisie van die lykdig. Alhoewel dit byna as 'n parodie op die sierlike sewentiende-eeuse lykdig beskou sou kon word, handhaaf dit tog die beginsel van decorum waarvolgens die styl en inhoud van die lykdig moet harmonieer met die staat van die gestorwene. Dit is duidelik dat die byna ongeërgde toon en onttrokkenheid van die spreker aansluit by die introverte aard van die gestorwene (soos voorgehou in die reëls "hy't hulle sy hart belet" in strofe 5 sowel as "salfsaf / en skaam" in strofe 6). Daarbenewens word die uitgeteerdheid van die gestorwene (vgl. "maer en uitgeteer / net been en seningvleisies" in strofe 2) gereflekteer in die 'skraalheid' of gestrooptheid van die versifikasie wat gekenmerk word deur die gebruik van kort reëls met min informasie, kort strofes met 'n beperkte aantal rymklanke (abac dbdc ebec ens.) en die klein aantal strofes. Die mededeling in die gedig is ook gestroop van emosie sodat die hele idee van 'n smartlike rou enersyds daardeur ondermyn maar andersyds juis beklemtoon word:

$6 \mathrm{sal}$ hom dra

3 seuns 2 meisies

en die ma

'n klomp drentel saam

maer en uitgeteer

net been en seningvleisies

visgraat en hoenderveer

en 'n naam

hinkend agterna

soos in 'n impetieke reisies 
josef die kreupel tswana

in die santekraam

hulle kan bg. agterna

as hulle lus het

met trane voordra

of verontagsaam

daar was rusies in die huis

hy't hulle sy hart belet

tog was dit alles pluis

salaam

want gesien agteraf

vra sus Altabet

was hy salfsaf

en skaam

Anders as in die geval van die vorige gedig wat oor 'n bekende staatsman gehandel het, moet die leser uit die narratio in die gedig probeer aflei wie en hoe die gestorwene was. Uit die eerste strofe se beskrywing van die draers ("6 sal hom dra / 3 seuns 2 meisies / en die ma") kan die afleiding dalk gemaak word dat die gestorwene ' $n$ jongmens was wat na die graf gedra sal word deur vriende of familielede en sy ma. Aan die ander kant mag dit wees dat die gestorwe "herman" verwant is aan 'n ander Herman in die bundel naamlik "Herman Knus Slaplat" wat saam met "Nanna Koue Patat van Silwer" figureer in die voorlaaste gedig in Allotroop "oopooggebed aan ontbyttafel". As die leser hierdie verband voorop sou stel, kan die gestorwene van die lykdig gelees word as 'n ouer man in plaas van 'n jongmens. Die draers ("3 seuns 2 meisies / en die ma") sou dan sy familie bestaande uit vyf kinders en hulle ma kon wees ('n gegewe wat so opvallend ooreenkom met die situasie van die digter Cloete dat die leser hier 'n element van outobiografiese fantasie sou kon vermoed). Die laaste reël van die strofe ("'n klomp drentel saam") skep die indruk van 'n jammerlike prosessie wat amper as ' $n$ bespotting van die georkestreerdheid van byvoorbeeld 'n staatsbegrafnis gelees kan word.

Soos reeds beweer, is lofspraak en beskrywing dikwels vervleg in die sewentiende-eeuse lykdig. Die kriptiese, selfs wrede, beskrywing van die dooie in die tweede strofe van hierdie gedig sou byna as 'n ironiese vorm van lofspraak gesien kon word. Die jammerlike fisiese toestand van die gestorwene ("maer en uitgeteer / net been en seningvleisies / visgraat en hoenderveer") 
suggereer iemand wat so deur siekte en lyding verrinneweer is dat daar weinig meer oorgebly het as 'n naam en reputasie. Die derde strofe sit weer die beskrywing van die jammerlike begrafnisstoet voort wanneer daar gefokus word op "josef die kreupel tswana" (binne die Suid-Afrikaanse konteks waarskynlik in meer as een opsig 'n sosiaal uitgeworpene) wat agterna hink. Die spreker in die gedig registreer op byna koelbloedig-onttrokke wyse die makabere van hierdie begrafnisstoet wanneer hy dit vergelyk met "'n impetieke reisies" en 'n "santekraam". Die woord "impetiek" (deur die WAT verklaar as die "hele klomp, boel, spul, tros, pakkasie - minagtend, ergerlik gesê van onwelkome besoekers") versterk saam met die woord "santekraam" ('n woord wat ook beteken "die hele spul, boel" en as wisselvorm het "santepetiek") die indruk van die begrafnisstoet as ' $n$ groteske en hoogs ironiese resies waaraan 'n boel ongenooides deelneem met die kreupele heel agter.

$\mathrm{Na}$ 'n pouse aangedui deur 'n asterisk, vervolg die gedig in die vierde strofe met 'n self-refleksiewe moment waarin die spreker nog steeds die ongeërgde toon volhou wat sterk kontrasteer met die plegtigheid van byvoorbeeld die Nederlandse lykdigte uit die sewentiende eeu. Vir die spreker is dit skynbaar om 't ewe watter rol die voorgaande drie strofes gaan speel by die afloop van die begrafnisseremonie: "hulle kan bg. agterna / as hulle lus het / met trane voordra / of verontagsaam". In hierdie vlugtige metapoëtiese moment laat blyk die spreker wel 'n bewustheid van die agterblywendes se rou (vgl. "met trane voordra") maar klink hy argeloos oor die moontlikheid om troos te verskaf soos wat dikwels in die lykdig gedoen word.

Die laaste twee strofes fokus op Herman en die verhouding met sy huisgenote. Volgens die vyfde strofe was daar wel onenigheid in die huis omdat die gestorwene die ander "sy hart belet" het, maar "tog was dit alles pluis". Die sesde en laaste strofe van die gedig verskaf 'n verklaring vir die gestorwene se introverte gedrag. Volgens die spreker (wat hier die outoriteit van "sus Altabet" byroep) was dit slegs 'n masker vir iemand wat "salfsaf / en skaam" was. Hierdie beskrywing roep naas die figuurlike ook die letterlike beeld op van ' $n$ bedlêende, sag van die salf wat aan hom gesmeer word (binne hierdie konteks word ook die woord "agteraf" in die eerste reël van die strofe dubbelsinnig). Hierdie verduidelikings is dan saam met die beskrywing in strofe 2 die enigste voorbeelde van die skamele lofprysing wat die byna bruuske spreker in hierdie gedig homself veroorloof. Die volle emosionele impak van hierdie sterfte (sy dit dié van 'n jong seun of 'n alter ego van die digter) blyk juis uit dit wat nie gesê word nie. Die leser kry in hierdie gedig die gevoel dat sy - soos die huisgenote van Herman - die spreker se "hart belet" is. Ook met hierdie byna parodiërende en groteske weergawe van 'n lykdig wat moontlik 'n 
vooruitskouing op sy eie dood is en waarin (self)spot afgewissel word met erns, voeg Cloete iets nuuts toe tot 'n ou tradisie.

\section{6. "Allofrasie"}

Die gedig "Allofrasie", die enigste van die vyf gedigte wat nie deur die titel geïdentifiseer word as lykdig nie, stem waarskynlik die meeste ooreen met die tradisionele lykdig. Die gedig demonstreer sonder die ironie en spot van die voorafgaande gedig die wisselende emosies wat volg op die dood van 'n geliefde persoon en rangskik hulle weer eens rondom die tradisioneel-retoriese elemente van rou, lof en vertroosting:

\section{Allofrasie}

D. Dit denken aan u wil zuiver zijn

Beauty, and love, are like distress.

Dit is geskryf met die diepste eerbied by die bedwing van ons ergste verdriet.

Distress, like white powder, is noiseless.

Dit is iets wit en stil en allerliefliks wat weg is. Die liefde bedek niks.

Liefste Seun, ons ontsteltenis stel ons uit. Nou is ons nog vreemd en druk besig om orbluf ons slakdoppie geluk se weerstand te toets. Ons vertel jou geliefste grappe vir mekaar oor en ons lag ons soutoog daarvoor.

Die dood maak met gevreesde verdrag klaar. Ondefinieerbaar onvanpas opgewonde is ons. Die bekende word hinderlik. Jou hond se oë. Wat sien hulle in ons s'n? Verwag hulle ons moet jou speletjies speel met hulle? hulle jou toertjies beveel?

Alles van jou het vatmerke wat pla en is vaskykvasloopplekke. Ons prakseer moeilik hoe ons jou moet aforganiseer of behou. Ons versit jou tekens, dra jou stukstuk rond, weg. Jou pen dáár, hiér 'n fles met 'n verslane sluk van jou laaste bier. 
Tam agter die dood se camouflage dwaal ons aan. Ons het gaan kyk: die ongeluk het op so 'n leë plek plaasgevind, 'n stuk onbenullige pad, verlate, in 'n so vaal landskap. Dis so 'n verbysterende seer om ons verontruste bewussynsprosesse te prosesseer.

Daar was 'n gierige dwang om die wrak te sien, die vonkproppe met jou bloed gevlek.

Die mens se maaksels is brutaal. Op die plek waar jy gesit het lê die gebluste masjien.

Ek moet vergeet, kop hou, iemand aanstel vir telegramme, iemand om blomme te bestel, ander vir die berei van die fees van die verdriet met tee en brood, die afsluk van die verlies - die kos wat oorbly kan mens bevries - liewer oor- as te kort skiet.

Die konvensioneel driedaags uitgestelde begrafnis maak ' $n$ beveiligende familie- en vriendegeskiedenis, lyflik - baie is reeds hier by ons bymekaar, van grootvader tot by agterkleinnig.

Soos vir Leonid en Lenie skryf ek jou lykdig, vir party is dit byna of iemand verjaar; mens sien die jong klomp vertroulik sit onder die bome, doofstom Frikkie loop en bid spokige vingertaal wat die meeste nie verstaan nie. Die liefde verplig ons tot die pierrotiese ritueel van die truggee van die liefde, deels stil seremonieel, deels met vertrokke lag, sing, bid, 'n allofrasie, al word die lewendes deur elke dooie opnuut afgerig daarvoor. Sonder Die liefde is die dood oorbodig.

Later voorsien ek gaan jou borsbeen steek deur ons hart, ons klere se nate oopbars van die slag, met die smaak van vars bloed sny ons ribbes deur ons longe, breek albei ons arms, probeer ons takties bepaal hoe die dood mens trefseker binnehaal. 
Nooit had só baie jou só lief soos in jou kis nie

al is daar iets onnoemliks wat ons afweer

en al stuit ons teen jou entropie. Jy ignoreer

ons maar jy weet nie wat jy jammerlik mis nie.

Die mistieke groot bruis, die beroerde gewemel

om jou sonder jou. Sien jou in die hemel.

"Allofrasie", verwys volgens woordeboeke na 'n "vreemde manier van praat, veral met ongewone sinsbou en samehang, wat dikwels voorkom by opgewondenheid of insinking van die bewussyn, asook by hardop droon" $(W A T)$. Met hierdie titel sinspeel die spreker waarskynlik op die ontstelde gemoed wat blyk uit hierdie lykdig oor die dood van 'n seun (volgens sekere bronne die digter se skoonseun - Gräbe, 1985). Dit is 'n ontsteltenis wat telkens in die gedig na die oppervlak kom, soms byna onverwags in die middel van ' $n$ betoog oor iets anders om te dui op die "insinkings van die bewussyn" kenmerkend van allofrasie. Daarteenoor sou hierdie gedig met sy keurige sintaksis, logiese bou en uitsonderlike verstegniese beheer slegs in 'n heel aangepaste sin van die woord beskryf kon word as 'n "vreemde manier van praat, veral met ongewone sinsbou en samehang", dus as 'n voorbeeld van allofrasie. Die titel se verwysing na allofrasie staan ook in spanning met die subtitel waarin die voorneme uitgespreek word om suiwer te dink aan die gestorwene: "D. Dit denken aan u wil zuiver zijn". Die inleiding van hierdie gedig (waarin die rou as struktuurelement domineer soos gesuggereer deur die verwysing na "ons ergste verdriet" in die eerste strofe) bou voort op die verwysing na suiwerheid in die subtitel deur die klem te plaas op geluidloosheid, witheid, stilte en niksheid. Die verstrengelde redenasie van hierdie eerste strofe onderskei mettertyd nie meer tussen die ervaring van nood se geluidloosheid, die stil wit lieflikheid van die "beauty and love" wat saam met die gestorwene weg is en die geluidlose niks wat sy sterfte agterlaat nie. Volgens die laaste reël se herskrywing en weerspreking van 1 Korintiërs 13 vers 7 het die liefde nié die vermoë om alles te bedek nie: "Die liefde bedek niks". Die afleiding is dat dit juis die liefde vir die gestorwene is wat die nood van die spreker oop-dek of veroorsaak.

In die tweede strofe blyk dit dat die gestorwene direk aangespreek gaan word in hierdie gedig. Die aanvangswoorde "Liefste Seun" en die res van die gedig skep die indruk van 'n brief waarin die skrywer ook namens ander (vgl. die verwysings na "ons") gebeure rapporteer aan die ontvanger wat nie teenwoordig kan wees nie. Die ironie hiervan is natuurlik dat die gebeure waaroor gerapporteer word alles verband hou met die dood van die aangesprokene. In die tweede tot die sesde strofe domineer gevoelens van geskokte rou oor die 
gestorwene, hier gekombineer met die narratio. Die tweede strofe fokus op die reaksie van die geskokte agterblywendes en in teenstelling met byvoorbeeld die vers geskryf by geleentheid van Brezjnjef se dood, val die persoonlike trant van die roubeklag hier op. Ook in die Renaissancistiese poëtikas word dit aangeteken dat die rou gevoelvoller raak namate die verlies persoonliker is. Die luctus word in hierdie gedeelte ook, soos dikwels in die ouer lykdigte, vervleg met die vituperatio van die dood, in die beginreëls van die derde strofe voorgestel as iets wat met vreesaanjaende deeglikheid klaarspeel met die menslike lewe (vgl. "Die dood maak met gevreesde verdrag / klaar"). Hierdie strofe fokus ook op die vreemde opgewondenheid wat deel uitmaak van die rou ("onvanpas opgewonde"), voordat daar beweeg word na 'n demonstrasie van die uitwerking wat die verlies van die gestorwene het ('n vorm van die iacturae demonstratio of aanwys van die betekenis van die verlies wat dikwels nou verweef is met die lofprysing en die rou). Ook die vierde strofe konsentreer op die ervaring van gemis by die agterblywendes: daar word verwys na dinge met die gestorwene se "vatmerke" (r. 1), die "vaskykvasloopplekke" wat hy gelaat het (r. 2), sy "pen" (r. 5), en "'n fles met 'n verslane sluk van (sy) laaste bier" (r. 6). In die vyfde strofe word die dood geblameer as die een wat die gestorwene onsigbaar mak vir sy geliefdes deur te verwys na "die dood se camouflage". Soos wat by geleentheid gebeur in die sewentiende-eeuse lykdig, word ook gefokus op die doodsoorsaak om sodoende die verdriet oor die gestorwene tot uitdrukking te bring. Die motorongeluk op "'n stuk / onbenullige pad" (strofe 5), die "wrak", die vonkproppe met "bloed gevlek" en die "gebluste masjien" (strofe 6) word dus beskryf. Die spreker lê ook klem op die verwikkelde emosies wat die mens tydens die rouproses ervaar as hy praat van die "gierige dwang om die wrak te sien".

Dit wil voorkom asof die gebruiklike beskrywing van die begrafnis vanaf die laaste reëls van strofe 6 tot by die einde van strofe 9 die element van consolatio in die gedig verteenwoordig. In hierdie strofes word beskryf hoedat die smart afgereageer en vertroosting gevind word in die rituele van die begrafnis en wat daarmee gepaard gaan. Dit begin by die reëlings (strofe 6), die voorbereidings vir "die fees van verdriet" (strofe 7), die gevoel van veiligheid ervaar in die lyflike teenwoordigheid van familie en vriende (strofe 7), die skryf van hierdie lykdig (strofe 8) en die paradoksale verjaardagparty-atmosfeer van die geleentheid (strofe 8). Die afskeid wat saam met die begrafnisgebeure gaan, word in strofe 9 gesien as "die pierrotiese ritueel / van die teruggee van die liefde": die verwysing na Pierrot suggereer die verdriet van hierdie proses waarin dit gaan om 'n afstand doen van die geliefde sowel as die liefde. In die tiende strofe word die dood se wreedheid met skokkende fisiese direktheid ingeskryf in die vooruitskouing op die pynlikheid van die rouproses wat gaan 
volg wanneer die verdowende vertroosting van die rituele rondom die begrafnis verby is. Die pyn wat die agterblywendes nog sal ervaar, word voorgestel in terme van die sterwensoomblikke van die dooie. Enersyds gaan hulle gepynig word deur sý pyn: dit gaan sy borsbeen wees wat steek deur hulle hart (vgl. "Later voorsien ek gaan jou borsbeen steek / deur ons hart"). Andersyds word die agterblywendes se pyn gesien in terme van dit wat die gestorwene ervaar het tydens die motorongeluk: "ons klere se nate oopbars / van die slag, met die smaak van vars / bloed sny ons ribbes deur ons longe, breek / albei ons arms". Juis deur middel van hierdie intense identifikasie met die gestorwene tydens die rouproses leer die mens iets oor hoe die dood "die mens trefseker binnehaal", hoe dit is om self te sterf.

Die slotstrofe sluit die brief aan die gestorwene af en lewer met 'n mate van ironie kommentaar op die opbruising van liefde vir die gestorwene ervaar tydens die begrafnis (vgl. "Nooit had só baie jou só lief soos in jou kis nie"). Hierdie opwelling van liefde gaan gepaard met 'n gevoel van uit- en afgesluit wees van die gestorwene wat nie kan reageer nie ("al is daar iets onnoemliks wat ons afweer / en al stuit ons teen jou entropie"). In hierdie slotstrofe sentreer die rou dus in die afwesigheid van die gestorwene sowel as in die feit dat hy die hele gedoe van die begrafnis wat om sy ontwil plaasvind nie kan ervaar nie omdat hy dood is. Die spreker verwys daarna as 'n "mistieke groot bruis" wat suggereer dat die gebeure vir hom iets heiligs of transendentaals verteenwoordig. Daar kan dus ook vertroosting geput word uit die feit dat iets van God se teenwoordigheid te bespeur is in die lewensopbruising van die agterblywendes om die ontwil van die gestorwene. Ten slotte domineer die consolatio as hierdie lykdig-brief eindig met 'n nugter en selfs blymoedige groet: "Sien jou in die hemel". Weer eens sluit Cloete aan by die tradisionele lykdig deur te steun op die bekende elemente rou, lof en troos, maar vernuwe hy dit tog deur gebruik te maak van die brief-struktuur met sy intieme, geselserige toon (wat net op enkele punte neig om warrig te word soos in strofes 1 en 9).

\section{Slot}

Cloete lewer met hierdie groep van vyf lykdigte in Allotroop 'n besondere bydrae tot die reeds uitgebreide korpus dodegedigte in die Afrikaanse poësie deurdat hy struktureel en tematies inspeel op 'n retoriese tradisie wat via die lykdigte van die Nederlandse Renaissance 'n brug slaan na die Klassieke verlede. Hy slaag egter ook daarin om hierdie eeue-oue tradisie te verbreed deur op bepaalde punte ondermynend, ironiserend of selfs parodiërend daarmee om te gaan. 


\section{Bronne}

Brink, André P. 1985. Cloete se nuwe bundel sy kragtigste. Rapport, Julie 7.

Cloete, T.T. 1985. Allotroop. Kaapstad : Tafelberg.

Gilfillan, F.R. 1985. Cloete-verse is 'n literêre verowering. Die Burger, Feb. 6.

Gräbe, Ina. 1985. Belangrike variasies op vorige temas. Die Transvaler, Julie 4.

Grové. A.P. 1985. Allotroop een van die belangrikstes. Beeld, Julie 1.

Hambidge, Joan. 1985. Moeilik om die droefnis te stelp. Die Vaderland, Mei 13.

Hugo, Daniel. 1985. Bundel wek die indruk van oordaad. Die Volksblad, Junie 8.

Kannemeyer, J.C. 1990. Geskiedenis van die Afrikaanse literatuur 1652-1987. Kaapstad : Human \& Rousseau.

Leeman, A.D. \& Braet, A.C. 1987. Klassieke retorica. Haar inhoud, functie en betekenis. Groningen : Wolters-Noordhoff/Forsten.

Louw, N.P. van Wyk. 1962. Tristia. Kaapstad : Human \& Rousseau.

Roberts, R.H. \& Good, J.M.M. 1993. The Recovery of Rhetoric. Persuasive Discourse and Disciplinarity in the Human Sciences. London : Bristol Classical Press.

Simons, Herbert W. 1990. The Rhetorical Turn. Invention and Persuasion in the Conduct of Inquiry. Chicago \& London : The University of Chicago Press.

Van Zyl, E.A. 1987. Die dodegedig in Afrikaans. Johannesburg : RAU. (M.A.-verhandeling.)

Witstein, S.F. 1969. Funeraire poëzie in de Nederlandse Renaissance. Assen : Van Gorcum. 